\title{
An Analysis of Differences in Terms of Professional Interests Based on the Project to Replace IAS 39
}

\author{
Cláudia Daniela Ferreira da Mota Carvalho \\ Instituto Politécnico de Lisboa, Departamento de Contabilidade, Lisboa, Portugal \\ Fábio Henrique Ferreira de Albuquerque \\ Instituto Politécnico de Lisboa, Departamento de Contabilidade, Lisboa, Portugal \\ Joaquín Texeira Quirós \\ Universidade Autônoma de Lisboa, Departamento de Ciências, Econômicas e Empresariais, Lisboa, Portugal
}

Maria do Rosário Fernandes Justino

Instituto Superior de Contabilidade e Administração de Lisboa, Departamento de Gestão, Lisboa, Portugal

Received on 04.29.2014 - Desk acceptance on 05.26.2014- $4^{\text {th }}$ version approved on 03.11.2015

\begin{abstract}
The professional interests of the various stakeholders groups are often seen as obstacles to full accounting harmonization. Studying different professional interests in the accounting domain is significant for organizations involved in the international accounting harmonization process, insofar as it enables them to identify the main obstacles to face in order to achieve full harmonization. Thus, this article is aimed at analyzing the differences in terms of professional interests by addressing the participation of various stakeholders groups in the process of issuing/modifying standards of the International Accounting Standards Board (IASB). Based on content analysis, we examined the comment letters sent to the IASB in the context of the first part of the first phase of the project to replace the International Accounting Standard (IAS) 39, entitled "Financial Instruments - Recognition and Measurement", by the International Financial Reporting Standard (IFRS) 9, on its turn entitled "Financial Instruments". Respondents were identified according to the stakeholders group, and, later, the collected data underwent a nonparametric chi-square test. The results of this study indicate there are significant differences between the answers obtained from the various stakeholders groups involved in the process of issuing or reviewing a standard of the IASB, above all made clear between the group of financial preparers and the regulatory and/or standard-setting agencies and the professional associations related to accounting.
\end{abstract}

Keywords: stakeholders groups, accounting harmonization, professional interests, international accounting standards. 


\section{INTRODUCTION}

Nobes and Parker (2006) argue that accounting has undergone changes since the Second World War, due to political transformations (such as the free movement of people and goods), the strong growth of international trade and the internationalization of financial markets and companies. This increasing globalization makes it necessary to reduce differences between the international accounting systems, in order to increase the comparability level between financial statements of companies from various countries (Nobes \& Parker, 2006).

So, one of the main aims of accounting harmonization is to achieve comparability between a financial report published by member countries of the various accounting systems. In the accounting harmonization process, the work provided by the International Accounting Standards Board (IASB) stands out, the issuing agency of high quality accounting standards accepted in most countries in the world.

The IASB is an independent issuer of accounting standards and interpretations and financial reporting of international reach, created in 2001, through a restructuring of the International Accounting Standards Committee (IASC), created, on its turn, in 1973. It is a member of the International Financial Reporting Standards (IFRS), whose goal is promoting the use and strict application of the standards and interpretations of the IASB and the recognition of a high quality and comprehensiveness of such standards and interpretations on the part of the adopting countries (International Financial Reporting Standards Foundation, 2013).

It is worth emphasizing that, prior to the reformulation of the IASB, the international standards were named International Accounting Standards (IAS), issued by the now defunct IASC. Later, these standards were adopted by the IASB.

The international standards issued by the IASB have been widely accepted object on the international scene, with numerous cases of application, directly or by adapting such standards. Particularly, the European Union (EU) has adopted, under the shelter of Regulation 1606/2002/EC, from the European Parliament and Council, enacted on July 19, the IASB standards, on a mandatory basis, for all entities with securities admitted to trading on any EU regulated market. The same regulation provides that member States include, either on a mandatory or discretionary basis, other entities in the context where these standards are adopted.

The accounting approach to the financial instruments has always been regarded as a complex topic (International Financial Reporting Standards Foundation, 2009), including, inter alia, issues such as derivative securities (or derivatives), hybrid financial instruments (or composites), and hedge accounting. In addition to IFRS 9 - Financial Instruments, which is currently going through an approval process with stages, there are cur- rently in force three IASB standards that regulate issues related to financial instruments concerning themes on presentation, recognition, and measurement and disclosure, namely:

- IAS 32 - Financial Instruments: Presentation. This standard establishes the principles for presenting financial instruments. It applies to the classification of financial instruments from the issuer's viewpoint;

- IAS 39 - Financial Instruments: Recognition and Measurement. This standard establishes the principles for recognizing and measuring financial assets and liabilities; and

- IFRS 7 - Financial Instruments: Disclosures. This standard sets out requirements for disclosure of information on financial instruments.

The complexity of the theme has also led to successive changes in the project to modify the issuing of the standard and, as a consequence, the calendar for its adoption. In November 2013, inter alia, some changes were made, with the inclusion of a chapter on hedge accounting and the date of application has changed, it was previously scheduled for January 1, 2015 (at the early stages of the project, January, 1, 2013, was expected as date of entry into force). After subsequent amendments, the latest version of IFRS 9, issued in 2014, replaced all previous versions, it must apply to periods beginning on or after January 1, 2018, with early adoption permitted (subject to the requirements of local backing).

In Portugal, the IASB standards were adapted to the national legislation through the Portuguese Accounting Standards and Financial Reporting (NCRF) issued by the Portuguese Accounting Standards Commission (CNC). NCRF 27 - Financial Instruments is the Portuguese standard adapting to the national regulations, at the same time, IAS 32, IAS 39, and IFRS 7 mentioned above.

In Brazil, the Brazilian Accounting Pronouncements Committee (CPC) is the body responsible for adapting the international standards issued by the IASB. International accounting standards related to financial instruments were adapted to the Brazilian legislation through statements that cover the same names of the standards on which they are based, namely:

- CPC 38 - Financial Instruments: Recognition and Measurement, prepared through IAS 39;

- CPC 39 - Financial Instruments: Presentation, prepared through IAS 32; and

- CPC 40 - Financial Instruments: Disclosure, prepared through IFRS 7.

It is worth noticing, finally, that the text of IFRS 9 currently in force has not undergone public discussion, either in Portugal or Brazil. 
IASB standards are principle-based standards, thus leaving room for professional discretion with regard to accounting decisions through concepts specifically outlined in the standards. The existence of subjective concepts in the standards, as well as the possibility of using accounting policies to the detriment of other policies also provided for in the standards, may impair the comparability of financial statements, since factors such as the professional interests of each stakeholders group can influence on professional judgment. In this sense, it is worth noticing there are, indeed, differences between the accounting preferences of the various stakeholders groups and whether these interests are reflected in contributions submitted to the IASB by each of these groups in the process of issuing or reviewing a standard.

Thus, this article is aimed at investigating differences in terms of professional interests among the users of financial information by addressing the participation of respondents in the processes of issuing/modifying IASB standards in order to provide an answer to the question pointed out in the preceding paragraph. In other words, given the significance of the standard under analysis, in view of the complexity of the issues included in its scope, the main motivation for this study stems from the need to understand whether respondents' professional interests are reflected in contributions sent to IASB during the process of public discussion of a standard. This issue is evaluated through differences in terms of position shown considering the various stakeholders groups participating in such processes. Also, as already indicated, CPC pronouncements, in Brazil, and the NCRFs from $\mathrm{CNC}$, in Portugal, are based on the IASB standards, and that is the reason why modifications made to international standards are especially relevant concerning financial reporting in the context of both countries, analyzed herein as an example.

For the purposes of this study, the questions raised for discussion by the IASB to preparers and users of financial information and standard-setting agencies regarding the first part of the first phase of the project to replace IAS 39 by IFRS 9 will be analyzed.

It is worth mentioning that, under the objectives proposed for this study, comments submitted by participants in the discussion process promoted by the IASB were analyzed without identifying, though, whether these comments were, wholly or partly, incorporated by the specific agency.

Authors such as Carmo, Ribeiro and Carvalho (2011) and Jorissen, Lybaert and Van de Poel (2006) argue that the participants in this process have different interests (often contrary), something which leads the answers obtained to vary. The studies on which provided this article with a basis examined the answers sent to standard setters from various perspectives: Tandy and Wilburn (1996) address the participation of academics; Georgiou (2010) analyzes the participation of investment ma- nagement firms; authors such as Jorissen et al. (2006), Orens, Jorissen, Lybaert and Van Der Tas (2011), and Holder, Karim, Lin and Woods (2013) relate the answers obtained with factors such as culture, tax system, countries' characteristics or whether the use of IFRS is required or permitted in respondents' country of origin Huian (2013) examines which are the most participatory stakeholders groups and Carmo, Mussoi and Carvalho (2011) analyze the impact of comments in the process of issuing the standards from the viewpoint of potential groups of interest associated with the process (lobbying).

This study differs from the others, on the one hand, given the choice of subject matter, insofar as it analyzes the existence of different interests on the part of participants in the regulatory review process, based on the discussion of the project to replace IAS 39. This standard is particularly significant in the context of the work developed by the IASB, arousing great interest among the stakeholders of financial information, due to the complexity of the issues included in its scope, particularly in the context of the recent economic and financial crisis of international reach. On the other hand, previous studies about the comment letters received by the IASB have examined such answers from various perspectives. However, in more specific terms, only the studies by Carmo, Ribeiro et al. (2011) and Adhikari, Betancourt and Alshameri (2014) have a strong similarity to this, to the extent that they analyze the differences on the answers proposed by the various stakeholders. This is, however, a different research, because in the first case, the study object accounted for only four questions related to the discussion paper on the IFRS for Small and Medium-Sized Entities (IFRS for SMEs) and, in the second case, the study object was the document issued by the Securities and Exchange Commission (SEC) in order to guide the preparation of financial reporting in accordance with IFRS standards.

The findings shown by these studies do not coincide, since in Carmo, Ribeiro et al. (2011) there is no evidence of different answers depending on the group of interest, whereas in the study by Adhikari et al. (2014) there is evidence of different positions, depending on the respondents' group of interest. Thus, despite the different professional interests, it is not clear that they influence the answers sent to standard-setting agencies within the scope of issuing/modifying accounting standards.

Studying differences in terms of the professional interests of various stakeholders groups is significant to the countries and organizations involved in the international accounting harmonization process, insofar as it allows noticing the main obstacles to face in order to achieve full harmonization. Even at an advanced stage of the harmonization process, it is expected that this and other studies within this field of research keep providing the support needed to decision-making on the part of the agencies that issue international standards, as well as the national agencies in charge of adopting these standards. 


\section{THEORETICAL FRAMEWORK}

The IASB standards are characterized by their principles-based approach. This is characterized by dictating principles instead of regulating every possible situation, and, when there is any doubt, people resort to the principle concerned. The principles are defined in the conceptual framework, accompanied by some rules that show how these principles should be applied to specific situations. This approach promotes consistency and transparency, providing the companies with answers in complex and new situations and it implies the need that professionals put professional discretion into practice (Guerreiro, 2008).

The IASB standard-setting process allows all interested parties to participate in public discussions and express an opinion through comment letters.

According to Jorissen et al. (2006), the standardization processes make it possible, in most cases, that stakeholders participate and influence these processes. Since the IASB standard-setting process also allows, over several phases, stakeholders' participation in the development/ modification of the standards through comments regarding the proposed amendments, there are studies examining the influence of factors such as culture or the legal system in relation to the origin of the comments received.

There are numerous studies that evaluate the participation of stakeholders groups in the standardization processes of the Financial Accounting Standards Board (FASB), the IASB, and the Accounting Standards Board (ASB) in the United Kingdom (Tandy \& Wilburn, 1996; Georgiou, 2010; Zülch \& Hoffmann, 2010; Jorissen et al., 2006; Giner \& Arce, 2012; Holder et al., 2013; Huian, 2013).

Tandy and Wilburn (1996) were pioneers in this kind of research by analyzing the participation of academics in the procedures for issuing the standards from the FASB. They conclude, in the study carried out, that academics get involved in the procedures when they have conducted investigations related to the topics under discussion and can contribute by means of their studies and one of the main reasons for the poor participation of this professional class is related to the poor expectations that their views may influence the final decisions.

The study by Anacoreta and Silva (2005) analyzes on a statistical basis the comment letters received by the IASB as part of the introduction of the IFRS standard for SMEs, with the purpose of identifying answer patterns. In the study pointed out, researchers tried to see whether small and medium-sized companies (SMEs) aim at a harmonized accounting and whether the opinions in this context are similar. They concluded that there is a group of answers whose characteristic is having no opinion with regard to the IASB questions. They also identified two groups among the answers with an opinion, a group that prefers independent standards for SMEs and another group that prefers interdependence between the two sets of standards.
Jorissen et al. (2006) have analyzed the opinions expressed by accounting professionals and standard setters sent to the IASB through comment letters between 2002 and 2005 , in an attempt to establish links between the countries' involvement level in the standardization processes and the characteristics of each country. Among the many assumptions made in this study, some related to the cultural values of Hofstede (1980) and the characteristics of the countries (e.g. non-compliance with regulation costs, tax system) were identified. Jorissen et al. (2006) conclude that the countries where the costs of non-compliance with standards are higher, accounting professionals try to influence the standardization process. Countries with high levels of compliance with the standards, with effective judicial systems, and where tax obligations are met have a more active participation in standardization processes. Regarding the cultural variables of Hofstede (1980), mixed results were obtained, but only in relation to the cultural value of power distance we managed to find a relationship, concluding that high levels of power distance negatively influence participation in the IASB standardization processes.

The study by Yen, Hirst and Hopkins (2007) shows the analysis of comments submitted to the FASB as an answer to the Exposure Draft (ED) issued during the discussion related to the comprehensive outcome. In this study, the arguments submitted by respondents, in order to understand how the entities try to persuade the FASB, were categorized and analyzed. The results demonstrate that most of the arguments submitted are related to concerns associated with the entity they represent. Relationships were found between the proposed amendments and modifications made to the ED that resulted in the final standard, something which suggests that the FASB takes into account the opinions expressed.

Georgiou (2010) analyzes the answers to a questionnaire related to participation in the IASB processes to issue standards by investment management firms in the United Kingdom. The study reveals that participation in this kind of company is not as low as it is thought to be, because some companies participate through representative agencies, such as associations of investment management firms and that the factor inhibiting these companies to participate is the cost involved in participation. The results also show that these companies think that the accounting professionals, the European standard setters, and the United Kingdom are the dominant groups and they have greater power to influence the process of issuing the IASB standards.

Orens et al. (2011) analyze, through questionnaires applied to professionals in Belgium and the United Kingdom, whether the decision to participate in the IASB standard-setting process is related to the legal system in the country. The authors conclude that companies not listed in Belgium, contrary to what occurs in the United Kingdom, hardly participate in standardization processes, and they tend to influence the IASB through audit firms. Unlisted companies in Belgium think the 
participatory process is less effective than unlisted companies in the United Kingdom, and one of the main reasons for not participating in the process is the fact they feel that opinions do not influence the IASB. It is also concluded that preparers of financial information in Belgium are more involved in the IASB standard-setting process than non-preparers of financial information. Thus, the results seem to confirm the theory that the regulatory system in the country of origin influences the participation in standardization processes.

Carmo et al. (2011) analyzed the influence of groups of interest (lobbying) in the IASB standard-setting process. They concluded that only the opinions of accounting professionals, standard setters, and academics influence the IASB's final decision.

Huian (2013) analyzes the involvement level of key stakeholders groups in the development of new accounting standards related to impairment of financial instruments. The results suggest that Europeans and preparers of financial information are the major players, accounting professionals and users are the ones who agree with the new rules, and nearly half of the other groups disagree with the rules. Geographically, the greatest opposition is coming from Europe and Australia, while international organizations have rather balanced opinions.

Holder et al. (2013) analyzed the comment letters received by the FASB and the IASB as part of the amendments proposed to IAS 37 and the Financial Accounting Standard (FAS) 5. They examined how the answers are affected due to the fact that the use of IFRS is mandatory or permitted in the country of origin of the answers. Greater support for the modifications proposed by the IASB than those proposed by the FASB was found. The IASB has received more answers from countries that permit or require the use of IFRS than countries subject to national standards. Respondents from countries where the use of IFRS is permitted or required tend to respond less favorably to the modifications proposed to the ED, citing the significance to support their positions.

Larson and Herz (2013) addressed the participation level of various countries and the factors that influence the geographical diversity of the comment letters submit- ted to the IASB from 2001 to 2008. The authors concluded that the most involved countries are those in the EU and those with rather developed capital markets, and $55 \%$ of answers were received from 7 countries: Australia, Canada, France, Germany, Switzerland, United Kingdom, and USA. They found, too, that countries that historically have higher accounting differences from the IASB standards are more participatory. In most countries, the stakeholders groups of accounting professionals, national standard setters, and accounting firms send at least half of the letters. In the study conducted, the authors also found that when a standard affects particularly one or more countries, their participation tends to increase.

Adhikari et al. (2014) examined the comment letters sent to the SEC in the context of issuing a proposal for a guide to the use of IFRS in order to identify the level at which respondents support this proposal, whether there were different positions depending on the respondent's group and also if preparers' answers varied according to the characteristics of the company they represented. The authors concluded that, although most respondents agree with a group of global high quality accounting standards, an identical majority did not agree with the proposals in the document, identifying that answers vary according to respondents' characteristics, too.

A literature review on studies that use the comment letters received by the IASB within the regulatory review processes as study object have analyzed the answers from different perspectives. The analysis of differences concerning the answers obtained from various stakeholders groups involved in such processes, however, has been relatively neglected in the literature on the theme. This study aims to investigate whether there are differences in the answers obtained by the IASB, given the different characteristics and interests of various stakeholders groups, just like the study by Carmo, Ribeiro et al. (2011). However, these authors used a different study object, namely, the standard on IFRS for SMEs, identifying potentially inconclusive results.

Table 1 displays distinctions between the groups more frequently used in studies aimed at analyzing the comment letters. 
Table 1

Most usual respondents groups in studies analyzing comment letters

\begin{tabular}{|c|c|c|c|c|c|c|}
\hline Respondent & $\begin{array}{l}\text { Carmo, Ribeiro et al. } \\
(2011)\end{array}$ & $\begin{array}{c}\text { Carmo, Mussoi et al. } \\
(2011)\end{array}$ & $\begin{array}{l}\text { Holder et al. } \\
\qquad(2013)\end{array}$ & Huian (2013) & $\begin{array}{l}\text { Jorissen et al. } \\
\qquad(2006)\end{array}$ & Saemann (1999) \\
\hline Companies & $\begin{array}{l}\text { Other companies and } \\
\text { business associations }\end{array}$ & Preparers & $\begin{array}{l}\text { Preparers - } \\
\text { Nonfinancial }\end{array}$ & Preparers & Preparers & $\begin{array}{c}\text { Financial } \\
\text { Executives Institute }\end{array}$ \\
\hline $\begin{array}{c}\text { Business } \\
\text { associations }\end{array}$ & $\begin{array}{l}\text { Other companies and } \\
\text { business associations }\end{array}$ & Preparers & $\begin{array}{l}\text { Preparers - } \\
\text { Nonfinancial }\end{array}$ & Preparers & Preparers & - \\
\hline Accounting firms & Audit firms & $\begin{array}{l}\text { Accounting } \\
\text { professionals }\end{array}$ & $\begin{array}{l}\text { Accounting } \\
\text { professionals }\end{array}$ & $\begin{array}{l}\text { Accounting } \\
\text { professionals }\end{array}$ & $\begin{array}{l}\text { Accounting } \\
\text { professionals }\end{array}$ & $\begin{array}{c}\text { American Institute } \\
\text { of CPAs }\end{array}$ \\
\hline $\begin{array}{l}\text { Associations } \\
\text { of accounting } \\
\text { professionals }\end{array}$ & $\begin{array}{l}\text { Standard setters and } \\
\text { professional associations } \\
\text { related to accounting }\end{array}$ & $\begin{array}{l}\text { Accounting } \\
\text { professionals }\end{array}$ & $\begin{array}{l}\text { Accounting } \\
\text { professionals }\end{array}$ & $\begin{array}{l}\text { Accounting } \\
\text { professionals }\end{array}$ & $\begin{array}{l}\text { Accounting } \\
\text { professionals }\end{array}$ & - \\
\hline Academics & Academics & Academics & Others & Others & Academics & \\
\hline Banks & $\begin{array}{l}\text { Other companies and } \\
\text { business associations }\end{array}$ & Preparers & $\begin{array}{l}\text { Preparers - } \\
\text { Financial }\end{array}$ & Preparers & Preparers & - \\
\hline $\begin{array}{l}\text { Insurance } \\
\text { companies }\end{array}$ & $\begin{array}{l}\text { Other companies and } \\
\text { business associations }\end{array}$ & Preparers & $\begin{array}{l}\text { Preparers - } \\
\text { Financial }\end{array}$ & Preparers/users & Preparers & \\
\hline $\begin{array}{l}\text { Standard setters/ } \\
\text { regulators }\end{array}$ & $\begin{array}{l}\text { Standard setters and } \\
\text { professional associations } \\
\text { related to accounting }\end{array}$ & Standard setters & Others & Regulators & Standard setters & FASB \\
\hline Users & - & - & Users & Users & Users & $\begin{array}{c}\text { Association } \\
\text { for Investment } \\
\text { Management and } \\
\text { Research }\end{array}$ \\
\hline Others & Other participants & Others & Others & Others & Others & \\
\hline
\end{tabular}

The next section provides the methodological outline adopted to conduct the empirical study proposed for this article.

\section{METHODOLOGY}

This study analyzes the existence of significant differences in the answers submitted in the context of the comment letters in answer to the ED - Financial Instruments Classification and Measurement, concerning the project to replace IAS 39 by IFRS 9 (first part of the first phase of the project), based on the existence of various professional interests and having a ranking based on different stakeholders groups. The choice of this project is related to the fact that the accounting approach to financial instruments is regarded as a complex theme that involves issues in which it is possible to identify the influence of professional interests in the answers. Another factor that lies on the basis of this choice is related to the high participation rate, given the interest that the subject awakens in various stakeholders (among others, preparers, users of financial reporting, and the standard-setting agencies).

Jorissen et al. (2006) have tested in one of the assumptions the involvement level of professionals in the IASB process to issue standards depended on their professional qualification. The authors concluded that preparers of financial information tend to participate more than users, that the vast majority of answers came from professional associations, and that the agencies most directly affected by the standards participate more actively. They also argue that participants in the process of discussing the standards respond in defense of their interests and that these interests often differ from and conflict with the interests of other professionals. Particularly, the interests of information users may differ from the interests of preparers. Although advocating for the existence of differences in the answers provided by the various stakeholders groups, Jorissen et al. (2006) have not analyzed the existence of differences between the answers obtained, only the answers related to factors such as the national characteristics of the respondent countries.

Carmo, Ribeiro et al. (2011) think, in the same sense, that respondents have different interests and, therefore, the answers may vary. However, despite conducting a study on the existence of differences between the answers, only four questions of the discussion paper on the IFRS for SMEs were analyzed. Since this is a standard aimed at small entities and taking into account that most respondents in the process of issuing/modifying standards work in large companies, the existence of differences between the answers motivated by different interests may not be apparent. 
According to Cortese, Irvine and Kaidonis (2010), large accounting/audit multinational firms collaborate with the IASB not only through technical comments, but also through monetary support. Saemann (1999) thinks that accounting professionals may take various positions in the standard issuing processes, and the participation of professionals aims at ensuring that the public interest is met. Thus, accounting professionals seek to ensure, simultaneously, the interests of users of financial information and their clients/employees/associates, advocating for the existence of higher disclosure and uniformity levels and lower conservatism levels.

According to Durocher, Fortin and Côté (2007) and Georgiou (2010), the main purpose of user participation in the process of issuing standards of the IASB is to achieve financial statements with relevant and transparent information for decision making. Saemann (1999) believes that users of financial information have a greater interest in uniform financial statements, since this increases comparability between companies, making the financial information more noticeable. They also prefer high disclosure levels.

According to Zeff (2006), the main purpose of preparers' participation in the standard issuing process is related to the maintenance of flexibility when managing outcomes in the financial statements. Thus, the preparers of financial information usually take an unfavorable position with regard to uniform practices. Saemann (1999) thinks that preparers are opposed to accounting practices that require higher costs, such as, for instance, retrospective application of new practices. The author also believes that preparers usually take unfavorable positions with regard to high disclosure levels, since, besides increasing costs for preparing the financial statements, they make companies more transparent, making it easier to detect unfavorable results. According to Saemann (1999), preparers of financial information tend to oppose to accounting practices that increase volatility in the financial statements, showing a more conservative attitude.

The main purpose of regulators/standard setters, when participating in the process of issuing the IASB standards, is to ensure the issue of standards that provide useful information for decision making (Saemann, 1999). The IASB believes that they play a key role in collaboration with the IASB for preparing high quality accounting standards (International Financial Reporting Standards Foundation, 2013). According to Zeff (2006), government agencies tend to advocate for legislation that meets the interests of domestic enterprises. Saemann (1999) argues that these organizations tend to reflect the goals of users of financial information, i.e. preference for greater uniformity, transparency, and lower conservatism.

Larson, Herz and Kenny (2011) believe that the participation of academics and their research play a major role to develop high-quality accounting standards. According to Tandy e Wilburn (1996), academics play a key role in the process of issuing standards, as they are economically independent and have the theoretical knowledge needed for a correct evaluation of the proposals.

In view of previous research, the following hypothesis was defined for this study:

General hypothesis: There are significant differences between the answers obtained by the IASB in the context of the ED "Financial Instruments: Classification and Measurement", in view of the various stakeholders groups participating in the process.

The classification of answers obtained is appropriate, given the study features and purposes, just like those conducted by Jorissen et al. (2006), Carmo, Ribeiro et al. (2011), Holder et al. (2013), Huian (2013), among others.

So, based on the literature review presented, the classification of respondents will be based on the following distinction: nonfinancial preparers, financial preparers, accounting professionals, academics, standard setters and professional associations related to accounting and users (Carmo, Ribeiro et al., 2011; Holder et al., 2013).

To carry out the study proposed, data were collected from the answers to the ED analyzed by the authors of this study. Such answers, as mentioned above, were sent to the IASB through comment letters between July 14, 2009, and September 14, 2009. Within this period, 246 comment letters regarding financial instruments were submitted to the IASB, and 10 situations where their content was inaccessible. Additionally, one respondent sent 2 comment letters, 2 letters did not bring any identification of the country of origin, and only 2 respondents just made comments, not answering any of the questions actually asked. Thus, 231 answer letters to the first phase of the exposure draft were analyzed, the subject of this article. Access to the comment letters was obtained through the website of the IFRS Foundation. Where appropriate, the information providing respondents' characterization with a basis, in view of the literature review conducted, was identified by means of the respective websites informed in the answers sent.

The methodology used to examine the comment letters was content analysis, through which the data needed to prepare this study were obtained. This approach is defined by Weber (1990) and cited by Yen et al. (2007) as a research method that uses a set of procedures aimed to draw inferences from a given text. According to the author, content analysis is particularly useful because it enables transforming and encoding the text so that the research can be conducted. In this study, the approach adopted is qualitative content analysis, since the answers to the ED concerned were analyzed in view of the opinion expressed in relation to the amendments proposed.

The 15 questions posed in the ED were, at a first phase, analyzed and fragmented, in order to avoid having multiple questions at a single point. Through this fragmentation, there came 60 final questions, since the questions requiring alternative and additional explanations were excluded from the scope of this article. Thus, only 
20 questions underwent analysis, taking into account the possibility of a more objective coding way, depending on the agreement or disagreement with the proposal. These 20 questions are displayed in Table 2.

Table 2

Questions of the Exposure Draft (2009) selected for the study

\begin{tabular}{|c|c|}
\hline $\mathbf{N}$ & Question \\
\hline 1.1 & $\begin{array}{l}\text { Does amortized cost provide decision-useful information for a financial asset or financial liability that has basic loan features and is managed } \\
\text { on a contractual yield basis? }\end{array}$ \\
\hline 2.1 & $\begin{array}{l}\text { Do you believe that the ED proposes sufficient, operational guidance on the application of whether an instrument has 'basic loan features' and } \\
\text { 'is managed on a contractual yield basis'? }\end{array}$ \\
\hline 3.1 & $\begin{array}{l}\text { Do you believe that other conditions would be more appropriate to identify which financial assets or financial liabilities should be measured at } \\
\text { amortized cost? }\end{array}$ \\
\hline 3.2 & $\begin{array}{l}\text { If financial assets or financial liabilities that the exposure draft would be measured at amortized cost do not meet your proposed conditions, do } \\
\text { you think that those financial assets or financial liabilities should be measured at fair value? }\end{array}$ \\
\hline 4.1 & Do you agree that the embedded derivative requirements for a hybrid contract with a financial host should be eliminated? \\
\hline 4.2 & Do you agree with the proposed tranches? \\
\hline 5.1 & $\begin{array}{l}\text { Do you agree that entities should continue to be permitted to designate any financial asset or financial liability at fair value through profit or } \\
\text { loss if such designation eliminates or significantly reduces an accounting mismatch? }\end{array}$ \\
\hline 7.1 & Do you agree that reclassification should be prohibited? \\
\hline 8.1 & $\begin{array}{l}\text { Do you believe that more decision-useful information about investments in equity instruments results if all such investments are measured at } \\
\text { fair value? }\end{array}$ \\
\hline 9.1 & Are there circumstances in which the benefits of improved decision-usefulness do not outweigh the costs of providing this information? \\
\hline 10.1 & $\begin{array}{l}\text { Do you believe that presenting fair value changes for particular investments in equity instruments in other comprehensive income would } \\
\text { improve financial reporting? }\end{array}$ \\
\hline 10.2 & $\begin{array}{l}\text { Do you believe that presenting dividends for particular investments in equity instruments in other comprehensive income would improve } \\
\text { financial reporting? }\end{array}$ \\
\hline 11.1 & $\begin{array}{l}\text { Do you agree that an entity should be permitted to present in other comprehensive income changes in the fair value of any investments in } \\
\text { equity instruments (other than those that are held for trading), only if it elects to do so at initial recognition? }\end{array}$ \\
\hline 11.2 & $\begin{array}{l}\text { Should entities present changes in fair value in other comprehensive income only in the periods in which the investments in equity instruments } \\
\text { meet the proposed identification principle? }\end{array}$ \\
\hline 13.1 & Do you agree with applying the proposals retrospectively and the related proposed transition guidance? \\
\hline 14.1 & $\begin{array}{l}\text { Do you believe that the alternative approach of measuring at amortized cost only financial assets that meet the conditions specified in the ED } \\
\text { and meet the definition of loans and receivables in IAS } 39 \text { provides more decision-useful information than measuring those financial assets at } \\
\text { amortized cost? }\end{array}$ \\
\hline 15.1 & $\begin{array}{l}\text { Do you believe that the possible variant of measuring all financial assets at fair value provides more decision-useful information than the } \\
\text { alternative approach of measuring at amortized cost the financial assets that meet the conditions specified in the ED and meet the definition of } \\
\text { loans and receivables in IAS } 39 \text { ? }\end{array}$ \\
\hline 15.2 & $\begin{array}{l}\text { Do you believe that the possible variant of measuring all financial assets at fair value provides more decision-useful information than the } \\
\text { alternative approach of measuring at amortized cost the financial assets that meet the conditions specified in the ED? }\end{array}$ \\
\hline
\end{tabular}

It is worth noticing that, despite most respondents have followed the structure of the questions, some did not, just stating their general position. Some respondents gave brief answers, occasionally just "yes" or "no", and others provided an exhaustive answer, with examples, detailed explanations of their positions, and how the modifications would affect their organizations and, in some cases, they provided alternative hypotheses and suggestions for improvement. In some cases, an analysis of the answers was rather direct and, in other cases, rather subjective, requiring a more detailed examination to determine the respondent's position.
In order to conduct the study proposed, the questions were analyzed through their transformation into dichotomous variables, so the analysis has "yes" (agreement) or "no" (disagreement) to each of the questions, coded as "1" and "0", respectively, was regarded as enough to achieve the proposed goals, just like Carmo, Ribeiro et al. (2011).

Thus, according to Carmo, Ribeiro et al. (2011), accounting professionals include large accounting/audit firms.

This group of users includes the rating agencies, investors, investors associations, and individual answers 
(Holder et al., 2013).

Nonfinancial preparers include nonfinancial companies and their associations (Holder et al., 2013).

Financial preparers include financial institutions and financial institutions associations and financial professionals. Although financial institutions are often regarded as users of financial statements, due to their investment activities, they were regarded as preparers in this study, since they are the biggest users and developers of financial instruments (Chatham, Larson \& Vietze, 2010).
Regulatory bodies and/or professional associations related to accounting include the national standard-setting agencies, regulators of capital markets, other government agencies, and professional associations in the accounting area (Carmo, Ribeiro et al. 2011).

Finally, the answers from academics were considered in the group named "Academics" (Jorissen et al. 2006; Carmo, Ribeiro et al. 2011).

Table 3 shows the number of answers obtained according to the respondent's stakeholder group.

Table 3

Answers according to the respondent's stakeholder group

\begin{tabular}{|c|c|c|}
\hline Stakeholders group & Number of answers & Participation (\%) \\
\hline Regulatory/standard-setting agencies and professional associations related to accounting & 56 & $24 \%$ \\
\hline Professional association in the accounting area & 23 & $10 \%$ \\
\hline Regulatory/standard-setting agencies & 33 & $14 \%$ \\
\hline Financial preparers & 102 & $44 \%$ \\
\hline Business associations and financial professionals & 51 & $22 \%$ \\
\hline Financial companies & 51 & $22 \%$ \\
\hline Nonfinancial preparers & 31 & $13 \%$ \\
\hline Nonfinancial companies & 17 & $7 \%$ \\
\hline Business associations and nonfinancial professionals & 14 & $6 \%$ \\
\hline Accounting professionals & 10 & $4 \%$ \\
\hline Accounting/audit firms & 10 & $4 \%$ \\
\hline Users & 17 & $7 \%$ \\
\hline Users & 17 & $7 \%$ \\
\hline Academics & 15 & $6 \%$ \\
\hline Academics & 15 & $6 \%$ \\
\hline Overall total & 231 & \\
\hline
\end{tabular}

We observe that the most participatory stakeholders group in the discussion concerned was that of financial preparers and, in turn, accounting professionals, academics, and users were less participatory groups. The frequent participation of financial preparers may be seen as an outcome of the frequent use and promotion of financial instruments by financial institutions (Huian, 2013). On the other hand, the poor participation of academics and users in the accounting standardization processes is confirmed, just as previously identified in studies by Durocher et al. (2007) and Tandy and Wilburn (1996).

In this sense, and since the answers obtained from the groups of academics, accounting professionals, and users are not sufficiently representative (under 30), they will not be taken into account for the purposes of this study. Thus, the study population is reduced to a number consisting of 189 respondents.

To analyze the assumptions made, we used in this study the nonparametric chi-square test, usually employed in studies like this (e.g. Carmo, Ribeiro et al., 2011). The chi-square test was used in this study by means of the statistical software Predictive Analytics SoftWare (PASW), and a significance level (or p value) at $5 \%$ was used.

The next section is devoted to presenting the results obtained in view of the methodological outline described above.

\section{RESULTS}

This study aims to identify the existence of significant differences between the answers obtained and the various professional interests, having in mind the classification made on the basis of distinct respondents' stakeholders groups. Thus, we compare the answers of groups with representative participation: financial/ nonfinancial preparers (Table 4); regulatory and/or standard-setting agencies and professional associations related to accounting vs. nonfinancial preparers (Table 5); and, finally, regulatory and/or standard-setting agen- 
cies and professional associations related to accounting vs. financial preparers (Table 6). To this end, the questions raised for discussion by the IASB among preparers and users of financial information and standard-setting agencies will be analyzed concerning the first part of the first phase of the project to replace IAS 39 - Financial Instruments: Classification and Measurement by IFRS 9.

Table 4 displays the results obtained by comparing two groups: financial preparers and nonfinancial preparers.

Table 4 Results obtained from financial and nonfinancial preparers

\begin{tabular}{|c|c|c|c|c|c|c|c|c|c|c|c|}
\hline & \multicolumn{5}{|c|}{ Financial preparers } & \multicolumn{5}{|c|}{ Nonfinancial preparers } & \multirow{2}{*}{$\begin{array}{l}\text { Pearson's } \\
\text { chi-square }\end{array}$} \\
\hline & $\mathbf{0}$ & $\%$ & 1 & $\%$ & Total & $\mathbf{0}$ & $\%$ & 1 & $\%$ & Total & \\
\hline Question 1.1 & 4 & $5 \%$ & 78 & $95 \%$ & 82 & 2 & $8 \%$ & 23 & $92 \%$ & 25 & 0.553 \\
\hline Question 2.1 & 76 & $93 \%$ & 6 & $7 \%$ & 82 & 19 & $95 \%$ & 1 & $5 \%$ & 20 & 0.713 \\
\hline Question 3.1 & 17 & $21 \%$ & 65 & $79 \%$ & 82 & 4 & $17 \%$ & 20 & $83 \%$ & 24 & 0.660 \\
\hline Question 4.1 & 16 & $21 \%$ & 59 & $79 \%$ & 75 & 7 & $30 \%$ & 16 & $70 \%$ & 23 & 0.368 \\
\hline Question 4.2 & 6 & $8 \%$ & 67 & $92 \%$ & 73 & 1 & $7 \%$ & 13 & $93 \%$ & 14 & 0.892 \\
\hline Question 5.1 & 1 & $1 \%$ & 80 & $99 \%$ & 81 & 2 & $11 \%$ & 17 & $89 \%$ & 19 & 0.033 \\
\hline Question 6.1 & 51 & $73 \%$ & 19 & $27 \%$ & 70 & 4 & $24 \%$ & 13 & $76 \%$ & 17 & 0.000 \\
\hline Question 7.1 & 76 & $93 \%$ & 6 & $7 \%$ & 82 & 21 & $91 \%$ & 2 & $9 \%$ & 23 & 0.826 \\
\hline Question 8.1 & 22 & $26 \%$ & 63 & $74 \%$ & 85 & 2 & $8 \%$ & 22 & $92 \%$ & 24 & 0.067 \\
\hline Question 9.1 & 16 & $23 \%$ & 53 & $77 \%$ & 69 & 0 & $0 \%$ & 23 & $100 \%$ & 23 & 0.011 \\
\hline Question 10.2 & 76 & $86 \%$ & 12 & $14 \%$ & 88 & 21 & $81 \%$ & 5 & $19 \%$ & 26 & 0.482 \\
\hline Question 12.1 & 24 & $40 \%$ & 36 & $60 \%$ & 60 & 6 & $35 \%$ & 11 & $65 \%$ & 17 & 0.725 \\
\hline Question 13.1 & 53 & $74 \%$ & 19 & $26 \%$ & 72 & 11 & $73 \%$ & 4 & $27 \%$ & 15 & 0.982 \\
\hline Question 14.1 & 1 & $2 \%$ & 65 & $98 \%$ & 66 & 1 & $6 \%$ & 17 & $94 \%$ & 18 & 0.319 \\
\hline Question 15.1 & 0 & $0 \%$ & 64 & $100 \%$ & 64 & 0 & $0 \%$ & 19 & $100 \%$ & 19 & - \\
\hline Question 15.2 & 0 & $0 \%$ & 63 & $100 \%$ & 63 & 0 & $0 \%$ & 19 & $100 \%$ & 19 & - \\
\hline
\end{tabular}

It is observed, by analyzing Table 4, regarding financial and nonfinancial preparers, that the hypothesis is supported on answers to the questions 5.1, 6.1, and 9.1, and in the last two questions a greater amount of financial preparers who prefer fair value measurement is evidenced. It is also observable, having the answers to questions 15.1 and 15.2 as a basis, that both financial and nonfinancial preparers disagree $100 \%$ with a measurement of all financial instruments at fair value.

Table 5 identifies, in turn, the comparison of answers obtained from nonfinancial preparers and regulators and/or standard-setting agencies and professional associations related to accounting.

Table $5 \quad$ Results obtained from nonfinancial preparers and regulatory agencies

\begin{tabular}{|c|c|c|c|c|c|c|c|c|c|c|c|}
\hline & \multicolumn{5}{|c|}{ Regulators/professional associations related to accounting } & \multicolumn{5}{|c|}{ Nonfinancial preparers } & \multirow{2}{*}{$\begin{array}{l}\text { Pearson's } \\
\text { chi-square }\end{array}$} \\
\hline & $\mathbf{0}$ & $\%$ & 1 & $\%$ & Total & $\mathbf{0}$ & $\%$ & 1 & $\%$ & Total & \\
\hline Question 1.1 & 6 & $12 \%$ & 45 & $88 \%$ & 51 & 2 & $8 \%$ & 23 & $92 \%$ & 25 & 0.615 \\
\hline Question 2.1 & 51 & $96 \%$ & 2 & $4 \%$ & 53 & 19 & $95 \%$ & 1 & $5 \%$ & 20 & 0.814 \\
\hline Question 3.1 & 23 & $49 \%$ & 24 & $51 \%$ & 47 & 4 & $17 \%$ & 20 & $83 \%$ & 24 & 0.008 \\
\hline Question 4.1 & 18 & $37 \%$ & 31 & $63 \%$ & 49 & 7 & $30 \%$ & 16 & $70 \%$ & 23 & 0.601 \\
\hline Question 4.2 & 9 & $21 \%$ & 33 & $79 \%$ & 42 & 1 & $7 \%$ & 13 & $93 \%$ & 14 & 0.227 \\
\hline Question 5.1 & 1 & $2 \%$ & 45 & $98 \%$ & 46 & 2 & $11 \%$ & 17 & $89 \%$ & 19 & 0.144 \\
\hline Question 6.1 & 24 & $51 \%$ & 23 & $49 \%$ & 47 & 4 & $24 \%$ & 13 & $76 \%$ & 17 & 0.050 \\
\hline Question 7.1 & 34 & $67 \%$ & 17 & $33 \%$ & 51 & 21 & $91 \%$ & 2 & $9 \%$ & 23 & 0.025 \\
\hline Question 8.1 & 19 & $37 \%$ & 32 & $63 \%$ & 51 & 2 & $8 \%$ & 22 & $92 \%$ & 24 & 0.009 \\
\hline Question 9.1 & 16 & $34 \%$ & 31 & $66 \%$ & 47 & 0 & $0 \%$ & 23 & $100 \%$ & 23 & 0.001 \\
\hline Question 10.1 & 19 & $39 \%$ & 30 & $61 \%$ & 49 & 5 & $20 \%$ & 20 & $80 \%$ & 25 & 0.103 \\
\hline Question 12.1 & 6 & $14 \%$ & 36 & $86 \%$ & 42 & 6 & $35 \%$ & 11 & $65 \%$ & 17 & 0.069 \\
\hline Question 13.1 & 12 & $27 \%$ & 33 & $73 \%$ & 45 & 11 & $73 \%$ & 4 & $27 \%$ & 15 & 0.001 \\
\hline Question 14.1 & 43 & $93 \%$ & 3 & $7 \%$ & 46 & 1 & $6 \%$ & 17 & $94 \%$ & 18 & 0.886 \\
\hline Question 15.1 & 5 & $12 \%$ & 38 & $88 \%$ & 43 & 0 & $0 \%$ & 19 & $100 \%$ & 19 & 0.121 \\
\hline Question 15.2 & 4 & $10 \%$ & 37 & $90 \%$ & 41 & 0 & $0 \%$ & 19 & $100 \%$ & 19 & 0.159 \\
\hline
\end{tabular}


The results obtained in this analysis show that the hypothesis is confirmed only in the answers to questions 3.1, 7.1, 8.1, 9.1, and 13.1.

Regarding the question 3.1, it is observed that standard setters/professional associations related to accounting are divided concerning the increase of financial instruments measured at amortized cost, while nonfinancial preparers prefer, in most cases, increasing the application range of this method.

Regarding the question 7.1, we notice that, while standard setters/professional associations related to accounting are rather divided concerning the prohibition of reclassification, nonfinancial preparers are observed in $91 \%$ of the cases against the prohibition of reclassification of financial instruments.
Also concerning questions 8.1 and 9.1, standard setters/ professional associations related to accounting are rather divided. Thus, while financial preparers think, in $92 \%$ of the cases, that financial information does not become more useful if all financial instruments are measured at fair value, $100 \%$ of the answers identified situations where the benefit of measuring all financial instruments at fair value does not exceed the cost.

As for the question 13.1, it is found that, while $73 \%$ of the standard setters/professional associations related to accounting agree with the retrospective application of IFRS 9, the same percentage of nonfinancial preparers disagree with this measure.

Table 6 displays, finally, the results obtained on financial preparers versus standard setters/professional associations related to accounting.

Table 6

Results obtained from financial preparers and regulatory agencies

\begin{tabular}{|c|c|c|c|c|c|c|c|c|c|c|c|}
\hline & \multicolumn{5}{|c|}{$\begin{array}{l}\text { Standard setters/professional associations related to } \\
\text { accounting }\end{array}$} & \multicolumn{5}{|c|}{ Financial preparers } & \multirow{2}{*}{$\begin{array}{l}\text { Pearson's } \\
\text { chi-square }\end{array}$} \\
\hline & 0 & $\%$ & 1 & $\%$ & Total & $\mathbf{0}$ & $\%$ & 1 & $\%$ & Total & \\
\hline Question 1.1 & 6 & $12 \%$ & 45 & $88 \%$ & 51 & 4 & $5 \%$ & 78 & $95 \%$ & 82 & 0.143 \\
\hline Question 2.1 & 51 & $96 \%$ & 2 & $4 \%$ & 53 & 76 & $93 \%$ & 6 & $7 \%$ & 82 & 0.394 \\
\hline Question 3.1 & 23 & $49 \%$ & 24 & $51 \%$ & 47 & 17 & $21 \%$ & 65 & $79 \%$ & 82 & 0.001 \\
\hline Question 4.1 & 18 & $37 \%$ & 31 & $63 \%$ & 49 & 16 & $21 \%$ & 59 & $79 \%$ & 75 & 0.060 \\
\hline Question 5.1 & 1 & $2 \%$ & 45 & $98 \%$ & 46 & 1 & $1 \%$ & 80 & $99 \%$ & 81 & 0.683 \\
\hline Question 6.1 & 24 & $51 \%$ & 23 & $49 \%$ & 47 & 51 & $73 \%$ & 19 & $27 \%$ & 70 & 0.016 \\
\hline Question 7.1 & 34 & $67 \%$ & 17 & $33 \%$ & 51 & 76 & $93 \%$ & 6 & $7 \%$ & 82 & 0.000 \\
\hline Question 8.1 & 19 & $37 \%$ & 32 & $63 \%$ & 51 & 22 & $26 \%$ & 63 & $74 \%$ & 85 & 0.162 \\
\hline Question 9.1 & 16 & $34 \%$ & 31 & $66 \%$ & 47 & 16 & $23 \%$ & 53 & $77 \%$ & 69 & 0.199 \\
\hline Question 10.1 & 19 & $39 \%$ & 30 & $61 \%$ & 49 & 21 & $24 \%$ & 65 & $76 \%$ & 86 & 0.079 \\
\hline Question 10.2 & 32 & $65 \%$ & 17 & $35 \%$ & 49 & 76 & $86 \%$ & 12 & $14 \%$ & 88 & 0.004 \\
\hline Question 13.1 & 12 & $27 \%$ & 33 & $73 \%$ & 45 & 53 & $74 \%$ & 19 & $26 \%$ & 72 & 0.000 \\
\hline Question 14.1 & 43 & $93 \%$ & 3 & $7 \%$ & 46 & 1 & $2 \%$ & 65 & $98 \%$ & 66 & 0.160 \\
\hline Question 15.1 & 5 & $12 \%$ & 38 & $88 \%$ & 43 & 0 & $0 \%$ & 64 & $100 \%$ & 64 & 0.005 \\
\hline Question 15.2 & 4 & $10 \%$ & 37 & $90 \%$ & 41 & 0 & $0 \%$ & 63 & $100 \%$ & 63 & 0.011 \\
\hline
\end{tabular}

Table 6 shows a reasonable support for the existence of significant differences between the responses obtained with a view to professional respondent classification (financial preparer versus standard setter/professional associations related to accounting) concerning the answers 3.1, 4.2, 6.1, 7.1, 10.2, 12.1, 13.1, 15.1, and 15.2.

In the case of question 3.1, standard setters/professional associations are rather divided, while $79 \%$ of financial preparers think it is appropriate to increase the application range of amortized cost.

As for the question 4.2, it is observable that, while $21 \%$ of standard setters agree with the proposal of tranches, only $8 \%$ of financial preparers agree with this proposal, as this measure implies increasing financial instruments measured at fair value.

It is noticed that, concerning question 6.1, the category of standard setters is divided, while $73 \%$ of the financial preparers agree with the possibility that the fair value option is permitted in other cases.
Concerning the question 7.1, while standard setters are divided, $93 \%$ of the financial preparers disagree with the prohibition of reclassification of financial instruments.

The question 10.2 shows that $65 \%$ of standard setters/associations disagree with the measurement of dividends from financial instruments directly in other comprehensive income, while $86 \%$ of the financial preparers disagree with it.

Regarding further disclosure for companies that apply IFRS 9 before its effective date (question 12.1), standard setters agreed in $86 \%$ of cases, while only $60 \%$ of the financial preparers agree, something which indicates that they are rather divided as for disclosure issues.

Considering the question 13.1, it is observed that, while $73 \%$ of the standard setters are in favor of the retrospective application of the standard, $74 \%$ of the financial preparers are against such application, citing high costs. 
As for the questions 15.1 and 15.2, it is observed that $100 \%$ of the financial preparers do not agree with the measurement of all financial instruments at fair value. This percentage is reduced to $90 \%$ with regard to standard setters/professional associations related to accounting.

Overall, it is observed that preparers are often influenced by the costs that the application of measures implies, something which does not occur with standard setters/ professional associations related to accounting, which are rather focused on the quality of the information provided. It is also noticed that the preparers are more frequently opposed to uniform practices, disclosure practices, and less conservative practices, as opposed to standard set- ters/professional associations related to accounting, who have rather divided opinions concerning uniformity, disclosure, and conservatism, something consistent with that established by Saemann (1999).

Subsequently, Table 7 summarizes the results obtained and already presented in previous tables in the context of this study, considering the questions identified and the various stakeholders groups under analysis. Based on such results, it is possible to observe, in short, a greater number of significant differences (significance level lower than 5\%) when comparing financial preparers to standard-setting agencies or professional associations related to accounting.

Table 7 Summary of the results obtained in this study

\begin{tabular}{|c|c|c|c|}
\hline \multirow[b]{2}{*}{ Question } & \multicolumn{3}{|c|}{ Pearson's chi-square } \\
\hline & $\begin{array}{l}\text { Financial preparers vs. nonfinancial } \\
\text { preparers } \\
\text { (Table 4) }\end{array}$ & $\begin{array}{l}\text { Nonfinancial preparers vs. standard } \\
\text { setters/professional associations related to } \\
\text { accounting } \\
\text { (Table 5) }\end{array}$ & $\begin{array}{c}\text { Financial preparers vs. standard setters/ } \\
\text { professional associations related to } \\
\text { accounting } \\
\text { (Table 6) }\end{array}$ \\
\hline 1.1 & 0.553 & 0.615 & 0.143 \\
\hline 2.1 & 0.713 & 0.814 & 0.394 \\
\hline 3.1 & 0.660 & 0.008 & 0.001 \\
\hline 4.1 & 0.368 & 0.601 & 0.060 \\
\hline 4.2 & 0.892 & 0.227 & 0.043 \\
\hline 5.1 & 0.033 & 0.144 & 0.683 \\
\hline 6.1 & 0.000 & 0.050 & 0.016 \\
\hline 7.1 & 0.826 & 0.025 & 0.000 \\
\hline 8.1 & 0.067 & 0.009 & 0.162 \\
\hline 9.1 & 0.011 & 0.001 & 0.199 \\
\hline 10.1 & 0.646 & 0.103 & 0.079 \\
\hline 10.2 & 0.482 & 0.162 & 0.004 \\
\hline 12.1 & 0.725 & 0.069 & 0.005 \\
\hline 13.1 & 0.982 & 0.001 & 0.000 \\
\hline 14.1 & 0.319 & 0.886 & 0.160 \\
\hline 15.1 & - & 0.121 & 0.005 \\
\hline 15.2 & - & 0.159 & 0.011 \\
\hline
\end{tabular}

Finally, the next section shows the main conclusions, limitations, and prospects for further development identified for this study.

\section{CONCLUSIONS}

According to the results shown, it was possible to establish, in general terms, there are different positions among the various stakeholders groups, observable especially among the group of financial preparers and regulators and/or standard setters and professional associations related to accounting.

Thus, comparing the various stakeholders groups, we highlight the following key findings:

i. Financial preparers vs. nonfinancial preparers: according to the results obtained by analyzing Table 4 , there is evidence of differences between the group of financial preparers and the group of nonfinancial preparers regarding the answers obtained in only 3 questions, showing a larger amount of financial preparers who prefer fair value measurement.

ii. Nonfinancial preparers vs. regulatory and/or standard-setting agencies and professional associations related to accounting: according to the results obtained by analyzing Table 5, the group of nonfinancial preparers and the regulatory and/or standard-setting agencies and professional associations related to accounting, in turn, there is a greater 
divergence between the answers obtained, and the hypothesis is confirmed in about $1 / 3$ of the questions examined (more precisely, in 6 out of the 17 questions analyzed). Also, the regulatory agencies and/or standard-setting and professional associations related to accounting have more different answers from each other, while nonfinancial preparers have more homogeneous viewpoints shown in the answers.

iii.Financial preparers vs. regulatory and/or standard-setting agencies and professional associations related to accounting: according to the results obtained by analyzing Table 6 , the comparison between the answers obtained from financial preparers and regulators and/or standard setters and professional associations related to accounting shows, finally, a reasonable support for the existence of significant differences between various stakeholders groups, since out of the 17 questions discussed, 9 significantly differ (about half). This analysis has, in this sense, a rather strengthened support for the hypothesis proposed in this study, when compared to the results of the analysis shown.

It is also observed, in general terms, that preparers, either financial or nonfinancial, are more often opposed to uniform practices, disclosure practices, and less conservative practices, as opposed to standard setters/professional associations related to accounting, which have rather divided opinions when it comes to consistency, disclosure, and conservatism.

The existence of significant differences found in the answers, given the different stakeholders groups, is in line with the studies by Huian (2013) and Chatham et al. (2010) and it is opposite to the results obtained by Carmo, Ribeiro et al. (2011), who do not identify signi- ficant differences between the responses obtained from the groups mentioned.

For further research, it is suggested to conduct the study proposed at the other stages in the process to replace IAS 39 by IFRS 9, as well as the expansion of this study to other standards that are also undergoing a replacement process, thus covering other themes different from financial instruments.

The main limitation of this study refers to the research method adopted, content analysis, since it provides certain subjectivity to the study, especially in cases where the answers are unclear and hinder interpretation. The study of international differences in the domain of accounting and the various interests of stakeholders groups in financial information is significant to the countries and organizations involved in the international accounting harmonization process. Thus, we aim that the results obtained in this study provide the support needed to decision-making on the part of the agencies that issue international standards, as well as by national agencies in charge of adopting these standards.

Noticing the impact and incidence of concepts related to the accounting practice, based on professional discretion, contributes so that the goals behind the harmonization process, namely an effective comparability of financial reporting at the international level, are more easily achieved.

Further research may use the comment letters submitted to the national agencies responsible for issuing accounting and financial reporting standards as a study object, namely CNC (in Portugal) and CPC (in Brazil). Other investigations may also use as a study object public discussions provided by the IASB after issuing and/ or modifying a new standard, having in mind, inter alia, the evaluation of potential problems that are raised after its entry into force.

\section{References}

Adhikari, A., Betancourt, L., \& Alshameri, F. (2014). The SEC's proposed IFRS roadmap: an analysis of comment letters using content analysis and textual software. Journal of International Accounting, Auditing and Taxation, 23, 98-108.

Anacoreta, L., \& Silva, L. (2005). International accounting standards for SME's: an exploratory study (working paper). Porto: Universidade Católica Portuguesa.

Carmo, C., Mussoi, A., \& Carvalho, L. (2011). A influência dos grupos de interesse no processo de normatização contábil internacional: o caso do discussion paper sobre leasing. In Anais do $11^{\circ}$ Congresso USP de Controladoria e Contabilidade. São Paulo, SP. Recuperado de http:// www.congressousp.fipecafi.org/web/artigos112011/208.pdf

Carmo, C., Ribeiro, A., \& Carvalho, L. (2011). Convergência de fato ou de direito? A influência do sistema jurídico na aceitação das normas internacionais para pequenas e médias empresas. Revista Contabilidade Financeira, 22(57), 242-262.

Chatham, M., Larson, R., \& Vietze,-A. (2010). Issues affecting the development of an international accounting ștandard on financial instruments. Advances in Accounting, 26, 97-107.

Cortese, S., Irvine, H., \& Kaidonis, M. (2010). Powerful players: how constituents captured the setting of IFRS 6 , an accounting standard for the extractive industries. Accounting Forum, 34, 76-88.
Durocher, S., Fortin, A., \& Côté, L. (2007). User's participation in the accounting standard-setting process: a theory-building study. Accounting, Organizations and Society, 32, 29-59.

Georgiou, G: (2010). The IASB standard-setting process: participation and perceptions of financial statement users. The British Accounting Review, 42, 103-118.

Giner, B., \& Arce, M. (2012). Lobbying on accounting standards: evidence from IFRS 2 on share-based payments. European Accounting Review, 21(4), 655-691.

Guerreiro, M. (2008). Harmonização contabilística internacional: tendências internacionais. Revista Auditores e Revisores, 43, 46-53.

Hofstede, G. (1980). Culture's consequences: international differences in work-related values. Londres: Sage.

Holder, A., Karim, K., Lin, K., \& Woods, M. (2013). A content analysis of the comment letters to the FASB and IASB: accounting for contingencies. Advances in Accounting, 29, 134-153.

Huian, M. (2013). Stakeholder's participation in the development of the new accounting rules regarding the impairment of financial assets. Business Management Dynamics, 2(9), 23-35.

International Financial Reporting Standards Foundation. (2009). Constitution. Recuperado de http://www.ifrs.org/Current-Projects/ IASB-Projects/Financial-Instruments-A-Replacement-of-IAS-39- 
Financial-Instruments-Recognitio/Phase-I-Classification-andmeasurement/Pages/Phàse-I-Clasșification-and-measurement.aspx International Finaricial Reporting Standards Foundation. (2013). Constitution. Recuperado de http://www.ifrs.org/The-organisation/ Governance-and-accountability/Constitution/Documents/IFRSFoundation-Constitution-January-2013.pdf

Jorissen, A., Lybaert, N., \& Van de Poel, K. (2006). Lobbing towards a global standard setter - do national characteristics matter? An analysis of the comment letters written to the IASB. In Gregoriou, G. N., \& Gaber, M. (Eds.), International accounting: standards, regulations and financial reporting (pp. 1-40). Netherlands: Elsevier.

Larson, R., \& Herz, P. (2013). A multi-issue/multi-period analysis of the geographic diversity of IASB comment letter participation. Routledge, 10, 99-151.

Larson, R., Herz, P., \& Kenny, S. (2011). Academics and the development of IFRS: an invitation to participate. Journal of International Accounting Research, 10(2), 97-103.

Nobes, C., \& Parker, P. (2006). Comparative international accounting ( $9 \mathrm{a}$ ed.): London: Prentice Hall.

Orens, R., Jorissen, A., Lybaert, N., \& Van Der Tas, L. (2011). Corporate lobbying in private accounting standard setting: does the IASB have to reckon with national differences? Accounting in Europe, 8(2), 211-234.

Saemann, G. (1999). An examination of comment letters filed in the U.S. financial accounting standard-setting process by institutional interest groups. Abacus, 35(1), 1-28.

Tandy, P., \& Wilburn, N. (1996). The academic community's participation in standard setting: submission of comment letters on SFAS nos. 1-117. Accounting Horizons, 10(3), 92-111.

Weber, R. (1990). Basic content analysis (2a ed.). Newbury Park, CA: Sage. Yen, A., Hirst, D., \& Hopkins, P. (2007). A content analysis of the comprehensive income exposure draft comment letters. Research in Accounting Regulation, 19, 53-79.

Zeff, S. (2006). Comparative international accounting: political lobbying on accounting standards - national and international experience. London: Prentice Hall.

Zülch, H., \& Hoffmann, S. (2010). Lobbying on accounting standard setting in a parliamentary environment: a qualitative approach (HHL Working Paper n. 94). Leipzig: HHL Leipzig Graduate School of Management:

Correspondence address:

Cláudia Daniela Ferreira da Mota Carvalho

Instituto Politécnico de Lisboa

Avenida Miguel Bombarda, 1069-035, Lisboa

E-mail: claudia.carvalho@estradas.pt 